\title{
APPROACHES TO THE IDENTIFICATION AND ASSAY OF FLAVONOIDS IN BEE BREAD EXTRACTS BY SPECTROPHOTOMETRIC METHOD
}

\section{Hudz Nataliia ${ }^{1}$, Korzeniowska Karolina ${ }^{2}$, Wieczorek Piotr Paweł ${ }^{2}$, Schubertová Zuzana ${ }^{3}$, Brindza Ján ${ }^{3}$, Ivanišová Eva ${ }^{4}$}

\author{
${ }^{1}$ Faculty of Pharmacy, Danylo Halytsky Lviv National Medical University, Ukraine \\ ${ }^{2}$ Faculty of Chemistry, University of Opole, Poland \\ ${ }^{3}$ Institute of Biodiversity Conservation and Biosafety, Slovak University of Agriculture in Nitra, Slovak Republic \\ ${ }^{4}$ Faculty of Biotechnology and Food Sciences, Slovak University of Agriculture in Nitra, Slovak Republic
}
Received 25. 6. 2017
Revised 29. 6. 2017
Published 27.11.2017

Flavonoids are regarded as key compounds in bee bread. In this paper, quantitative determination of sum of flavonoids and dominating group of flavonoids were carried out by colorimetric aluminum chloride method. The principle of aluminum chloride colorimetric method is that aluminum chloride forms complexes with flavones and flavanols wherein it reacts with the C-4 keto group and hydroxyl groups of the ring $C$, and/or ring $A$ and/or ring $B$. In this work 3 samples of bee bread and 5 extracts were investigated. The total contents of flavonoids in the tested extracts ranged from 10 to $166 \mathrm{mg} / \mathrm{L}$. Our study confirmed that complex of quercetin dihydrate with aluminum chloride had the maximum absorption at $423.8-427.2 \mathrm{~nm}$, namely in the limits for flavanols from 415 to $440 \mathrm{~nm}$, in differential spectra in the range of quercetin concentrations of $2.08-31.2 \mathrm{mg} / \mathrm{L}$ (solvent was ethanol 50\%). According to literature data, flavanols (galangin, morin, kaempferol, rutin, quercetin, quercitrin and myricetin) have absorption maximum in the range from 415 to $440 \mathrm{~nm}$ while flavones (chrysin, apigenin, and luteolin) and glycosides of flavanols - less $415 \mathrm{~nm}$. Our studies demonstrated that the structure of direct spectra of developed extracts was very similar. There was no any absorption maximum. The structure of the differential spectra of all the developed extracts was also very similar. But there was one divergence in the differential spectra: an absorption maximum varies in the range from $406.9 \mathrm{~nm}$ to $411.7 \mathrm{~nm}$ that indicates different composition of flavonoids in the extracts. Repeatability of the position of an absorption maximum of the extracts is very good at carrying out analyses in the different days. On the base of conducted experiments, we assume that our bee bread samples can contain flavanols mainly in the form of glycosides and flavones as absorption maxima of the extracts in their differential spectra are less than $415 \mathrm{~nm}$.

Keywords: bee bread; flavonoids; spectra; extracts; quercetin

\section{Introduction}

Bee bread seems to be an attractive source of natural raw material for the food, cosmetics and pharmaceutical industry (Baltrušaityte et al., 2007; Ivanišova et al., 2015; Čeksteryte et al., 2016). Among the minor components of bee bread are phenolic compounds (Baltrušaityte et al., 2007; Markievicz-Żukovska et al., 2013; Rzepecka-Stojko et al., 2015; Sobral et al., 2017). Flavonoids are the secondary components of most importance in bee-bread. In pollen grains, most of flavonoids exist

\footnotetext{
*Corresponding author: Nataliia Hudz, Faculty of Pharmacy, Danylo Halytsky Lviv National Medical
} University, Ukraine, $\triangle$ natali_gudz@ukr.net 
as glycosides, among them flavanols glycosides are present in greatest amounts. Quercetin is known as the major aglycone in bee bread.

The level of free aglycones is a better indicator of the quality of pollen loads than the free amino acids content (Baltrušaityte et al., 2007; Zuluaga et al., 2014; Rzepecka-Stojko et al., 2015). Zuluaga et al. indicate that bee bread contains $3.2 \pm 1.0 \mathrm{mg}$ eq-quercetin/g with the reference the dry matter of bee bread. Average total flavonoid content in bee-pollen has been established in $5.16 \mathrm{mg}$ eq-quercetine/g bee-pollen (Zuluaga et al., 2014), a higher value than in bee-bread. Ivanišova et al. state about the high levels of phenolic substances and total flavonoids in the sample of bee bread from Ukraine. They employed aluminum colorimetric method for assay of sum of flavonoids at $415 \mathrm{~nm}$ (Ivanišova, 2015). Čeksteryte et al. also employed aluminum colorimetric method for assay of sum of flavonoids at 415 $\mathrm{nm}$ and identified quercetin and kaempferol in bee methanolic beebread extracts, 0.05 and $0.67 \mathrm{mg}$ per 1 gram of beebread, respectively (Čeksteryte, 2016). The presence of quercetin and kaempferol can be explained by that these aglycones are in more than $50 \%$ plants (Korulkin et al., 2007). The aim of this study was to measure content of flavonoids, evaluate the flavonoids composition of the extracts of beebread collected in Ukraine in 2015.

\section{Materials and methodology}

3 bee bread samples were used in that study. These samples were removed from the cells of the hives, packed in polypropylene bags and stored in refrigeration at $(2-8)^{\circ} \mathrm{C}$ until phytochemical analyses were performed. The samples were collected during summer of 2015 year in Ukraine. The hives were located in Vradivka of Mykolajiv region and Poltava region. Bee bread granules were put in containers, $50 \%(\mathrm{~m} / \mathrm{m})$ ethanol was added in necessary volume and extraction was carried out at $15-25^{\circ} \mathrm{C}$ with periodic stirring for 17-21 days at a ratio of raw material-solvent: $1: 10$ and $1: 5$ (maceration). Then extracts were filtered through filter paper. $50 \%$ ethanol was selected as solvent that extracts both hydrophilic and hydrophobic biologically active substances (BAS) (Фитохимический анализ..., 2009; Rzepecka-Stojko et al., 2015). Before carrying out analytical procedures extracts were additionally filtered through a filter with a pore size of 0.45 microns if necessary. Table 1 presents information about the tested bee bread samples and their extracts.

Table 1 Information about bee bread samples and prepared extracts

\begin{tabular}{|l|c|c|c|c|c|}
\hline No & $\begin{array}{c}\text { Number } \\
\text { of an extract }\end{array}$ & $\begin{array}{c}\text { Date of collection } \\
\text { of bee pollen }\end{array}$ & $\begin{array}{c}\text { Ratio of bee bread } \\
\text { to } \mathbf{5 0} \% \text { ethanol }\end{array}$ & $\begin{array}{c}\text { Dates of } \\
\text { extraction }\end{array}$ & $\begin{array}{c}\text { Time of } \\
\text { extraction }\end{array}$ \\
\hline $\mathbf{1}$ & 10416 & 15.07 .2015 & $10 \mathrm{~g}: 100 \mathrm{ml}$ & $19.04 .-10.05 .2016$ & 21 day \\
\hline $\mathbf{2}$ & 30416 & June 2015 & $10 \mathrm{~g}: 100 \mathrm{ml}$ & $19.04 .-10.05 .2016$ & 21 day \\
\hline $\mathbf{3}$ & 40516 & 02.08 .2015 & $20 \mathrm{~g}: 100 \mathrm{ml}$ & $10.05 .-27.05 .2016$ & 17 days \\
\hline $\mathbf{4}$ & 50516 & 15.07 .2015 & $20 \mathrm{~g}: 100 \mathrm{ml}$ & $10.05 .-27.05 .2016$ & 17 days \\
\hline $\mathbf{5}$ & 60516 & June 2015 & $20 \mathrm{~g}: 100 \mathrm{ml}$ & $10.05 .-27.05 .16$ & 17 days \\
\hline
\end{tabular}

Total flavonoid content was determined using the slightly modified method of differential spectrometry provided by Meda et al. (2005). The curve of quercetin dihydrate was plotted in a range of its concentrations of 2.08 to $31.2 \mathrm{mg} / \mathrm{L}$. $1 \mathrm{ml}$ of the obtained solutions of quercetin dihydrate were mixed with $1.0 \mathrm{ml}$ of $2 \%$ aluminum chloride hexahydrate in $50 \%$ ethanol. The amount of $2 \%$ aluminum chloride hexahydrate in $50 \%$ ethanol was substituted by the same volume of $50 \%$ ethanol in the 
blank for each dilution of quercetin dihydrate. Simultaneously, each blank for differential spectrum was used for measuring direct spectrum of quercetin using $50 \%$ ethanol as blank. After incubation at the room temperature for 65-85 min the direct and differential spectra of the reaction mixtures were measured in range of $360 \mathrm{~nm}$ to $460 \mathrm{~nm}$. In a like manner, the certain volume of an extract of bee bread was diluted with $50 \%$ ethanol up to $1.0 \mathrm{ml}$ and was mixed with 1.0 of $2.0 \%$ solution of aluminum chloride hexahydrate.

The mixture was mixed by vortex and incubation was done for 65-85 minutes at the room temperature. The amount of $2 \%$ solution of aluminum chloride was substituted by the same amount of $50 \%$ ethanol in the blank. The test was carried out for each bee bread extract in triplicate. Direct spectra of the extracts were determined according to the following procedure: the certain volume of an extract of bee bread was diluted with $50 \%$ ethanol up to $2.0 \mathrm{ml}$. $50 \%$ ethanol was used as a blank. In fact, each blank for a differential spectrum was used for measuring direct spectrum of an extract using 50\% ethanol as blank. For assay of flavonoids we used absorbance of the extracts and quercetin dihydrate solutions in absorption maxima in their obtained differential spectra, appropriate equations for quercetin dihydrate in $\mathrm{mg} / \mathrm{ml}\left(y_{1}=30.428 \cdot X-0.0262, R^{2}=0.9717\right.$ and $y_{2}=29.945$. $\left.X-0.0219, R^{2}=0,997\right)$ and necessary recalculations for volume of an extract taken for the assay.

\section{Results and discussion}

The results of the investigation of batches 10416, 30416, 040516, 050516 indicate that at an incorrect ratio of volumes of an extract of bee bread and $2 \%$ solution of $\mathrm{AlCl}_{3} \cdot 6 \mathrm{H}_{2} \mathrm{O}$ the absorbance of a reaction mixture is less than 0.05 or significantly higher 1.0 and the absorption maximum are shifted the right. In general, regularity was established: the more absorbance exceeds 1.0 the more absorption maximum is shifted the right. Absorbance of a reaction mixture was corrected with reducing the volume of an extract and compensation of deficiency of the volume of a reaction mixture with a volume of $50 \%$ ethanol. Secondly, our studies demonstrated that the structure of direct spectra of developed extracts was very similar. There was no any absorption maximum. The structure of the differential spectra of the tested extracts was also very similar. But there was one divergence in the differential spectra: an absorption maximum varies in the range from $406.9 \mathrm{~nm}$ to $411.7 \mathrm{~nm}$ that indicated different composition of flavonoids in the extracts (Figures 1a-f). Repeatability of the position of the absorption maximum of the extracts was very good at carrying out analyses in the different days (Table 2).
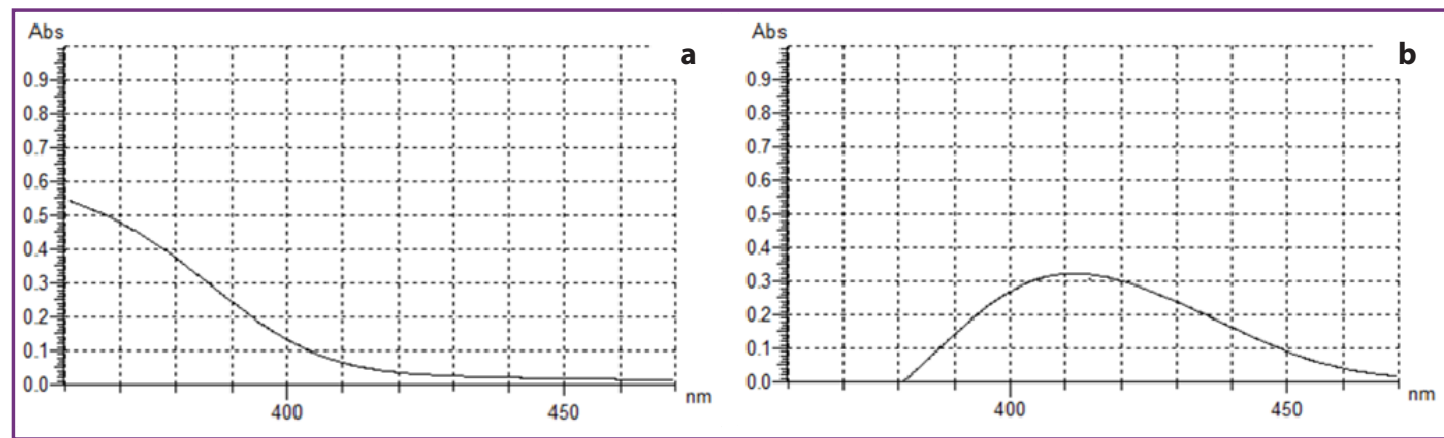

Figure 1a-b Direct spectrum of the extract a - No. 010416; b - No. 010416 with $\mathrm{AlCl}_{3}\left(\lambda_{\max }=412.0 \mathrm{~nm}, \mathrm{~A}=0.323\right) ; \mathbf{c}-$ No. 040516; d - No. 040516 with $\mathrm{AlCl}_{3}(\lambda \max =407.6 \mathrm{~nm}, \mathrm{~A}=0.483) ; \mathbf{e}$ - direct spectrum of quercetin $153 \mathrm{mg} / \mathrm{l}(\lambda \max =374.4 \mathrm{~nm}, \mathrm{~A}=0.548)$; $\mathbf{f}$ - differential spectrum of quercetin $153 \mathrm{mg} / \mathrm{l}$ with $\mathrm{AlCl}_{3}(\lambda \max =426.2 \mathrm{~nm}, \mathrm{~A}=0.540)$ 

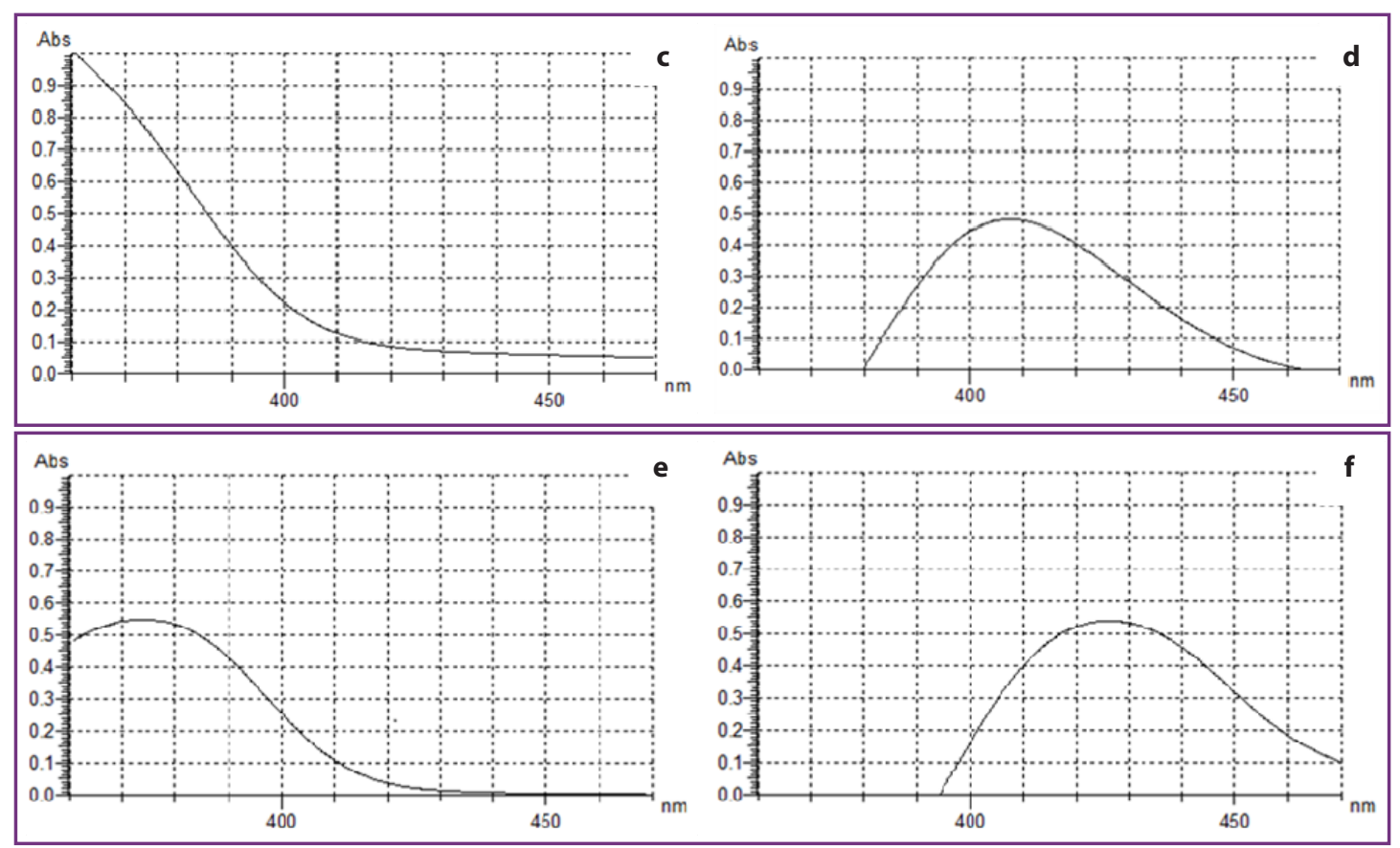

Figure 1c-f Direct spectrum of the extract a - No. 010416; b - No. 010416 with $\mathrm{AlCl}_{3}\left(\lambda_{\max }=412.0 \mathrm{~nm}, \mathrm{~A}=0.323\right) ; \mathbf{c}-$ No. 040516; d - No. 040516 with $\mathrm{AlCl}_{3}(\lambda \max =407.6 \mathrm{~nm}, \mathrm{~A}=0.483) ; \mathbf{e}-$ direct spectrum of quercetin $153 \mathrm{mg} / \mathrm{l}(\lambda \max =374.4 \mathrm{~nm}, \mathrm{~A}=0.548)$; f - differential spectrum of quercetin $153 \mathrm{mg} / \mathrm{l}$ with $\mathrm{AlCl}_{3}(\lambda \max =426.2 \mathrm{~nm}, \mathrm{~A}=0.540)$

The principle of aluminum chloride colorimetric method is that aluminum chloride mainly forms complexes with flavones and flavanols wherein it reacts with the C-4 keto group and either the C-3 hydroxyl group of the ring C, and/or C-5, C-7 hydroxyl group of the ring A and the C-3' or C-4' of the ring B hydroxyl groups (Chang et al., 2002). According to Chang et al., such flavanols as galangin, morin, kaempferol, rutin, quercetin, quercitrin and myricetin have absorption maximum at $415-440 \mathrm{~nm}$ (ethanol in concentration of $36,5 \%$ was as medium) while the absorption maximum of complexes formed by chrysin and apigenin which have only C-5 and C-7 hydroxyl and C-4 keto groups were at $395 \mathrm{~nm}$ and $385 \mathrm{~nm}$, respectively. Our study confirms these data: complex of quercetin with aluminum chloride had the maximum absorption at $423.8-427.2 \mathrm{~nm}$ in differential spectra in the range of quercetin dihydrate concentrations of $2.08-31.2 \mathrm{mg} / \mathrm{L}$ (figures $1 \mathrm{e}$ and $1 \mathrm{f}$ ). Another flavone luteolin having C-3', C-4', C-5 and C-7 hydroxyl groups had the maximum absorption of complex with Al at $415 \mathrm{~nm}$ (Chang et al., 2002). Baltrušaityte at al. (2007) identified kaempferol, chrysin and apigenin in bee bread.

Čeksteryte et al. (2016) identified kaempferol and quercetin and stated that flavonoids in the form of glycosides had been not found in bee bread. Markievicz-Żukovska et al. (2013) detected kaempferol and apigenin in bee bread. Sobral et al. (2017) recognized a lot of flavonoids derivates in bee bread among them were flavanol derivatives, mainly quercetin, kaempferol, myricetin, isorhamnetin and herbacetrin glycoside derivatives. 
Table 2 Analytical procedure and content of sum of flavonoids in bee bread extracts

\begin{tabular}{|c|c|c|c|}
\hline $\begin{array}{l}\text { Number of } \\
\text { an extract }\end{array}$ & Analytical procedure & $\begin{array}{c}\lambda \max \text { and } \\
\text { absorbance }\end{array}$ & $\begin{array}{l}\text { Sum of flavonoids, } \mathrm{mg} / \mathrm{L} \text {, time } \\
\text { of forming complex }\end{array}$ \\
\hline \multirow{3}{*}{10416} & $\begin{array}{c}0,5 \mathrm{ml} \text { of the extract }+1,0 \mathrm{ml} 2 \% \\
\mathrm{AlCl}_{3} \cdot 6 \mathrm{H}_{2} \mathrm{O}+0,5 \mathrm{ml} \text { of } 50 \% \text { ethanol }\end{array}$ & $413,2 \mathrm{~nm}, 1.435$ & $\begin{array}{c}63 \text { min, content of flavonoids was } \\
\text { not calculated }\end{array}$ \\
\hline & \multirow{2}{*}{$\begin{array}{l}0.1 \mathrm{ml} \text { of the extract }+1.0 \mathrm{ml} 2 \% \\
\mathrm{AlCl}_{3} \cdot 6 \mathrm{H}_{2} \mathrm{O}+0.90 \mathrm{ml} \text { of } 50 \% \text { ethanol }\end{array}$} & $410.9 \mathrm{~nm}, 0.327$ & $103.71,67 \mathrm{~min}$ \\
\hline & & $411.7 \mathrm{~nm}, 0.336$ & $106.41,74 \mathrm{~min}$ \\
\hline \multirow{2}{*}{30416} & $\begin{array}{l}0.5 \mathrm{ml} \text { of the extract }+0.5 \mathrm{ml} \text { of } 50 \% \\
\text { ethanol }+1.0 \mathrm{ml} 2 \% \mathrm{AlCl}_{3} \cdot 6 \mathrm{H}_{2} \mathrm{O}\end{array}$ & $410.6 \mathrm{~nm}, 0.144$ & $10.01,66 \mathrm{~min}$ \\
\hline & $\begin{array}{c}0.1 \mathrm{ml} \text { of the extract }+0.90 \mathrm{ml} \text { of } 50 \% \\
\text { ethanol }+1.0 \mathrm{ml} 2 \% \mathrm{AlCl}_{3} \cdot 6 \mathrm{H}_{2} \mathrm{O}\end{array}$ & $412.5 \mathrm{~nm}, 0.032$ & $17.11,80 \mathrm{~min}$ \\
\hline \multirow{2}{*}{40516} & $\begin{array}{l}1.0 \mathrm{ml} \text { of the extract }+1.0 \mathrm{ml} 2 \% \\
\qquad \mathrm{AlCl}_{3} \cdot 6 \mathrm{H}_{2} \mathrm{O}\end{array}$ & $426.3 \mathrm{~nm}, 1.941$ & $\begin{array}{c}\text { content of flavonoids was not } \\
\text { calculated }(20.07 .2016)\end{array}$ \\
\hline & $\begin{array}{l}0.1 \mathrm{ml} \text { of the extract }+1.0 \mathrm{ml} 2 \% \\
\mathrm{AlCl}_{3} \cdot 6 \mathrm{H}_{2} \mathrm{O}+0.90 \mathrm{ml} \text { of } 50 \% \text { ethanol }\end{array}$ & $407.3 \mathrm{~nm}, 0.516$ & $159.21,82 \mathrm{~min}$ \\
\hline \multirow{4}{*}{50516} & $\begin{array}{l}1.0 \mathrm{ml} \text { of the extract }+1.0 \mathrm{ml} 2 \% \\
\qquad \mathrm{AlCl}_{3} \cdot 6 \mathrm{H}_{2} \mathrm{O}\end{array}$ & $431.6 \mathrm{~nm}, 1.969$ & $\begin{array}{c}\text { content of flavonoids was not } \\
\text { calculated (20.07.2016) }\end{array}$ \\
\hline & $\begin{array}{c}0.5 \mathrm{ml} \text { of the extract }+1.0 \mathrm{ml} 2 \% \\
\mathrm{AlCl}_{3} \cdot 6 \mathrm{H}_{2} \mathrm{O}+0.5 \mathrm{ml} \text { of } 50 \% \text { ethanol }\end{array}$ & $419.3 \mathrm{~nm}, 1.697$ & $\begin{array}{c}69 \text { min, content of flavonoids was } \\
\text { not calculated }\end{array}$ \\
\hline & \multirow{2}{*}{$\begin{array}{l}0.1 \mathrm{ml} \text { of the extract }+1.0 \mathrm{ml} 2 \% \\
\mathrm{AlCl}_{3} \cdot 6 \mathrm{H}_{2} \mathrm{O}+0.9 \mathrm{ml} \text { of } 50 \% \text { ethanol }\end{array}$} & $410.1 \mathrm{~nm}, 0.539$ & $166.01,71 \mathrm{~min}$ \\
\hline & & $410.4 \mathrm{~nm}, 0.528$ & $162.71,86 \mathrm{~min}$ \\
\hline \multirow{2}{*}{60516} & $\begin{array}{l}1.0 \mathrm{ml} \text { of the extract }+1.0 \mathrm{ml} 2 \% \\
\qquad \mathrm{AlCl}_{3} \cdot 6 \mathrm{H}_{2} \mathrm{O}\end{array}$ & $411.5 \mathrm{~nm}, 0.440$ & $\begin{array}{c}\text { content of flavonoids was not } \\
\text { calculated (20.07.2016) }\end{array}$ \\
\hline & $\begin{array}{c}0.5 \mathrm{ml} \text { of the extract }+1.0 \mathrm{ml} 2 \% \\
\mathrm{AlCl}_{3} \cdot 6 \mathrm{H}_{2} \mathrm{O}+0,5 \mathrm{ml} \text { of } 50 \% \text { ethanol }\end{array}$ & $411.9 \mathrm{~nm}, 0.213$ & $14.02,74 \mathrm{~min}$ \\
\hline
\end{tabular}

\section{Conclusions}

The total contents of flavonoids in the extracts ranged from 10 to $166 \mathrm{mg}$ in $1 \mathrm{~L}$. Supposing that flavonoids are present in the form of aglycones we can assume that our beebread sample contain mainly flavones as the maximum absorbance of extracts in their differential spectra are less than $415 \mathrm{~nm}$, namely in the range of 406.9-411.7 nm. But on the other hand, according to D. Korulkin et al. (2007), there is the following regularity for absorption maxima of flavanols: at substitution of the C-3 hydroxyl group absorption maximum of complex of flavonoids with $\mathrm{AICl} 3$ is shifted the left. For this reason, we assume that our bee bread sample can contain flavanols mainly in the form of glycosides and flavones.

\section{Acknowledgments}

The publication was prepared with the active participation of researchers involved in the International network AgroBioNet of the Institutions and researchers for realization of research, education and development program «Agrobiodiversity for improving nutrition, health and life quality» and within the project ITMS 25110320 104. Co-author Nataliia Hudz thanks to the International Visegrad Fund 
for scholarship and research internships, during which were got the results and knowledge presented in this paper.

\section{References}

Baltrušaityte, V., Venskutonis, P.R., Čeksterytè, V. 2007. Radical scavenging activity of different floral origin honey and beebread phenolic extracts. Food chemistry, vol. 101, no. 2, p. 502-514. DOI: 10.1016/j. foodchem.2006.02.07

Barene, I., Daberte, I., Siksna, S. 2015. Investigation of bee bread and development of its dosage forms. Medicinos teorija it practika, vol. 21, no 1, p. 16-22. DOI:10.15591/mtp.2015.003

Čeksterytè, V., Kurtinaitienè, B., Venskutonis, P.R. et al. 2016. Evaluation of Antioxidant Activity and Flavonoid Composition in Differently Preserved Bee Products. Czech J. Food Sci., vol., p. 133-142.

Chang, Ch.-Ch., Yang, M.-H., Wen, H.-M., Chern, J.-Ch. 2002. Estimation of Total Flavonoid Content in Propolis by Two Complementary Colorimetric Methods. Journal of Food and Drug Analysis, vol. 10, no. 3, p. 178-182.

Ivanišová, E., Kačániová, M., Frančáková, H., Petrová, J., Hutková, J., Brovarskyi, V., Velychko, S., Adamchuk, L., Schubertová, Z., Musilová. J. 2015. Bee bread - perspective source of bioactive compounds for future. Potravinarstvo Slovak Journal of Food Sciences, vol. 9, no 1, p. 592-598. DOI: 10.5219/558

Markievicz-Żukovska, R., Naliwajko, S.K., Bartosiuk, E., Moskwa, J., Isidorov, V., Soroczyńska, J., Borawska, M. 2013. Chemical composition and antioxidant activity of bee bread, and its influence on the glioblastoma cell line (U87MG). J. Apic. Sci., vol. 57, no 2, p. 147-157.

Meda, A., Lamien, C.E, Romito, M. at al. 2005. Determination of the total phenolic, flavonoid and proline contents in Burkina Fasan honey, as well as their radical scavenging activity. Food Chemistry, vol. 91, p. 571-577.

Rzepecka-Stojko, A., Stojko, J., Kurek-Górecka, A., Gorecki, M., Kabala-Dzik, A., Kubina, R., Mozdzierz, A., Buszman, E. 2015. Polyphenols from bee pollen: structure, absorption, metabolism and biological activity. Molecules, vol. 20, no. 12, p. 21732-21749. DOI: 10.3390/molecules201219800

Sobral, F., Calhelha, R.C., Barros, L., Dueñas, M., Tomás, A., Santos-Buelga, C., Vilas-Boas, M., Isabel Ferreira I. 2017. Flavonoid Composition and Antitumor Activity of Bee Bread Collected in Northeast Portugal. Molecules, vol. 22, no. 2, p. 248. DOI: 10.3390/molecules22020248

Zuluaga, C.M., Serratob, J. C., Quicazana, M. C. 2015. Chemical, Nutritional and Bioactive Characterization of Colombian Bee-Bread. Chemical engineering transactions, vol. 43, p. 175-180.

Корулькин, Д.Ю., Абилов, Ж.А., Музычкина, Р.А., Толстиков, Г.А. 2007. Природные флавоноиды. Рос. акад. наук, Сиб. отд., Новосиб. ин-т органической химии. Новосибирск: Академическое изд-во "Тео". 232 с. ISBN 978-5-9747-0119-1.

Фитохимический анализ растительного сырья, содержащего флавоноиды. 2009. Методическое пособие по фармакогнозии. Иркутск. 67 с. 